\title{
MENGAJAR DI TPA \\ NURUL IMAN BONTOA
}

\author{
Amelia Weni \\ NIM: 19183770410386 \\ Email: ameliaweni028@gmail.com
}

1.Bentuk Kegiatan

Mengajar di TPA Nurul Iman

\section{Lokasi}

Desa

Balangloe

Tarowang, Dusun Bontoa

3.Hari/Tanggal

dan

\section{Waktu}

Kamis, 01 Oktober 2020

Jam : 16:00

4.Peserta yang Dilibatkan

Mahasiswa

KKLP,

Ustadz, Ustadza dan

Anak-anak Santri

\section{Alasan Diadakannya}

Untuk Mengajar sekaligus membantu Para Guru TPA dalam Proses Membaca
IQRA maupun ALQUR'AN

6.Tujuan dan Manfaat Saling berbagi ilmu,

7. Produk Kegiatan

Iqra dan Al-Quran

\section{Deskripsi Kegiatan}

Setelah sholat ashar di hari Kamis, tepat pada tanggal 01 Oktober 2020, saya dan teman-teman berkunjung ke TPA Nurul Iman untuk bergabung mengajar IQRA maupun AL-QUR'AN kepada adek-adek Santri. Pertama-tama kami memperkenalkan diri bahwa kami adalah Mahasiswa KKLP STIE- 
STKIP

YAPTI

JENEPONTO yang

berKKLP di Desa Baltar ini selama kurang lebih 2 bulan dan akan mengatur jadwal di setiap TPA yang ada di Desa Baltar. 


\section{Referensi Wajib}

- HERIANTO, H., \& Amir, A. S. (2020, September 10). Pedoman Pelaksanaan Kuliah Kerja Lapangan Plus (KKLP) Mahasiswa STIE dan STKIP YAPTI Jeneponto. https://doi.org/10.31219/osf.io/7dvpk 